\title{
Serotonin Hyperinnervation Abolishes Seizure Susceptibility in Otx2 Conditional Mutant Mice
}

\author{
Prem Prakash Tripathi, ${ }^{1,2}$ Luca Giovanni Di Giovannantonio, ${ }^{3,4}$ Alessandro Viegi, ${ }^{1,2}$ Wolfgang Wurst, ${ }^{5,6}$ \\ Antonio Simeone, ${ }^{3,4}$ and Yuri Bozzi ${ }^{1}$ \\ ${ }^{1}$ Istituto di Neuroscienze del Consiglio Nazionale delle Ricerche (CNR) and 'Laboratorio di Neurobiologia della Scuola Normale Superiore, 56100 Pisa, Italy, \\ ${ }^{3}$ CEINGE-Biotecnologie Avanzate, 80145 Naples, Italy, ${ }^{4}$ Institute of Genetics and Biophysics “A. Buzzati-Traverso," CNR, 80131 Naples, Italy, ${ }^{5}$ Institute of \\ Developmental Genetics, Helmholtz Zentrum München, 85764 Munich/Neuherberg, Germany, and ${ }^{6}$ Max Planck Institute of Psychiatry, Molecular \\ Neurogenetics, 80804 Munich, Germany
}

The homeobox-containing transcription factor 0tx 2 is crucially involved in fate determination of midbrain neurons. Mutant mice, in which $0 t x 2$ was conditionally inactivated by a Cre recombinase expressed under the transcriptional control of the Engrailed 1 (En1) gene $\left(E n 1^{\text {cre/+ }} ;\right.$ Otx $\left.2^{\text {flox/flox }}\right)$, show a reduced number of dopaminergic neurons and an increased number of serotonergic neurons in the ventral midbrain. Despite these developmental anatomical alterations, $E n 1^{\text {cre/+}} ; O t x 2^{\text {flox/flox }}$ adult mice display normal motor function. Here, we further investigated the neurological consequences of $O t x 2$ inactivation in adult En $1^{\text {cre/+}} ; O t x 2^{\text {flox/flox }}$ mice. Adult En $1^{\text {cre/+ }}$;Otx $2^{\text {flox } / f l o x}$ mice showed increased serotonin (5-HT) levels in the pons, ventral midbrain, hippocampus (CA3 subfield), and cerebral cortex, as indicated by HPLC and immunohistochemistry. Conversely, SERT (5-HT transporter) levels were decreased in conditional mutant brains. As a consequence of this increased 5-HT hyperinnervation, En1 ${ }^{\text {cre/+ }} ;$ Otx $2^{\text {flox/flox }}$ mice were resistant to generalized seizures induced by the glutamate agonist kainic acid (KA). Indeed, prolonged pretreatment of $E n 1^{\text {cre/+}}$; Otx $2^{\text {flox/flox }}$ mice with the 5-HT synthesis inhibitor para-chlorophenylalanine ( $\mathrm{pCPA}$ ) restored brain 5-HT content to control levels, fully reestablishing KA seizure susceptibility. Accordingly, c-fos mRNA induction after KA was restricted to the hippocampus in $E n 1^{\mathrm{Cre} /+} ;$ Otx $2^{\text {flox/flox }}$ mice, whereas a widespread c-fos mRNA labeling was observed throughout the brain of $E n 1^{\mathrm{Cre} /+} ; \mathrm{Otx} 2^{\text {flox/flox }}$ mice pretreated with pCPA. These results clearly show that increased brain 5-HT levels are responsible for seizure resistance in $\mathrm{EnI}^{\text {cre/+ }}$; Otx $2^{\text {flox/flox }}$ mice and confirm the important role of 5-HT in the control of seizure spread.

Key words: serotonin transporter; pCPA; kainic acid; hippocampus; seizures; epilepsy

\section{Introduction}

The homeobox-containing transcription factor Otx2 is required for regionalization, patterning, and neuronal differentiation in the midbrain (Simeone et al., 2002; Simeone, 2005). At the midbrain/hindbrain boundary, Otx2 specifies identity and number of dopaminergic versus serotonergic progenitors by antagonizing the Fgf8 (fibroblast growth factor 8) and Shh (sonic hedgehog) pathways and preventing ventral de-repression of the Nkx2.2 transcription factor (Puelles et al., 2003, 2004; Prakash et al., 2006). In dopaminergic progenitors, Otx 2 is coexpressed with

\footnotetext{
Received May 8, 2008; revised July 25, 2008; accepted Aug. 6, 2008.

This work was supported by grants from the Italian Association for Cancer Research, the European Community FP6 (EuTRACC Integrated Project LSHG-CT-2006-037445), and Fondazione Cassa di Risparmio di Roma (A.S.). Y.B. is a recipient of research grants from Parents Against Childhood Epilepsy (New York, NY) and the National Research Council [Consiglio Nazionale delle Ricerche (CNR)-Ricerche Spontanee a Tema Libero program]. The financial support from Fondo per gli Investimenti della Ricerca di Base (CHEM-PROFARMA-NET Project) of the Italian Government to Istituto di Neuroscienze del CNR is also acknowledged. We thank Giulio Cesare Cappagli, Adriano Tacchi, and the technical/administrative staff of the Istituto di Neuroscienze for excellent assistance, and Matteo Caleo, Massimo Pasqualetti, and Manuela Scali for helpful discussions.

Correspondence should be addressed to either of the following: Antonio Simeone, CEINGE-Biotecnologie Avanzate, via Comunale Margherita 482, 80145 Naples, Italy, E-mail: simeone@ceinge.unina.it; or Yuri Bozzi, Istituto d Neuroscienze del Consiglio Nazionale delle Ricerche, via G. Moruzzi 1, 56100 Pisa, Italy, E-mail: yuri@in.cnr.it. DOI:10.1523/JNEUROSCI.2208-08.2008

Copyright $\odot 2008$ Society for Neuroscience $\quad$ 0270-6474/08/289271-06\$15.00/0
}

Engrailed 1 (En1) (Puelles et al., 2004; our unpublished observations). In conditional mutant mice, in which Otx2 was inactivated by a Cre recombinase expressed under the control of the $E n 1$ promoter $\left(E n 1^{c r e /+} ;\right.$ Otx $\left.2^{\text {flox/flox }}\right)$, midbrain dopaminergic neurons were greatly reduced in number and most of their precursors underwent neurotransmitter fate switch, generating serotonin (5-HT)-positive neurons (Puelles et al., 2004). This alteration is maintained throughout life, because $E n 1^{\text {cre/+ }}$; $O t x 2^{\text {flox/flox }}$ adult mice still display reduced dopamine (DA) and increased 5-HT levels in the striatum and cerebral cortex (Borgkvist et al., 2006).

Psychiatric and neurological conditions, such as affective disorders and epilepsy, depend on dysfunctions of the serotonergic system. As regards the role of 5-HT in epilepsy, it is known that agents that elevate extracellular 5-HT levels (such as 5-HT reuptake blockers) inhibit seizures, whereas 5-HT depletion results in the lowering of seizure threshold (Mazarati et al., 2005; Bagdy et al., 2007). The ventral midbrain and limbic system are crucially involved in 5-HT-mediated control of seizures (Bagdy et al., 2007).

In this study, we characterized the effects of serotonergic hyperinnervation in $\mathrm{En}^{\text {cre/+}} ; \mathrm{Otx} 2^{\text {flox/flox }}$ mice, investigating whether elevated 5-HT might contribute to decrease seizure sus- 
ceptibility in these animals. Seizures were evoked by systemic administration of the glutamate receptor agonist kainic acid (KA), a widely used model to study behavioral, anatomical, and cellular consequences of seizures in rodents (Lothman and Collins, 1981; Ben-Ari, 1985; Schauwecker and Steward, 1997). Here, we show that 5 -HT hyperinnervation protects $E n 1^{\text {cre/+}}$; $O t x 2^{\text {flox/flox }}$ mice against KA-induced seizures.

\section{Materials and Methods}

Animals. The generation and genotyping of $\mathrm{En} 1^{\mathrm{Cre} /{ }^{+}}$; Otx $2^{\text {flox/flox }}$ mutant mice have been reported previously (Puelles et al., 2003, 2004). In particular, the $E n 1^{\mathrm{Crel+}}$ and the Otx $2^{\text {flox/+ }}$ mouse strains were maintained through continued breeding of at least seven generations with C57BL/ $6 \times \mathrm{DBA} 2 \mathrm{~F}_{1}$ mice. Then the two strains were mated to generate parental mice $\left(E n 1^{C r e /+} ; O t x 2^{f l o x /+}\right.$ and Otx $\left.2^{\text {flox/flox }}\right)$. Otx $2^{\text {flox/flox }}$ mice were chosen as controls, because they do not show any anatomical or behavioral abnormality with respect to wild-type animals (Puelles et al., 2003; Borgkvist et al., 2006). Adult (6 months of age; weight, 20-35 g) mice of both sexes were used. Animals were housed in a $12 \mathrm{~h}$ light/dark cycle with food and water available ad libitum. Experiments were conducted in conformity with the European Communities Council Directive of November 24, 1986 (86/609/EEC).

Drug treatments. Drug-free Otx $2^{\text {flox/flox }}$ and $\mathrm{En} 1^{\mathrm{Cre} /+} ; \mathrm{Otx} 2^{\text {flox/flox }}$ mice ( $n=3$ per genotype) were used for initial 5-HT and 5-HT transporter (SERT) immunohistochemistry. To deplete 5 -HT, mice $(n=5$ per genotype) received para-chlorophenylalanine (pCPA) (4-chloro-Lphenylalanine hydrochloride; Sigma-Aldrich; $10 \mathrm{mg} / \mathrm{ml}$ stock in saline) twice a day (at $\approx 10: 00$ A.M. and 6:00 P.M.) at a dose of $100 \mathrm{mg} / \mathrm{kg}$ intraperitoneally for 3 consecutive days (Rantamäki et al., 2007). Five $\mathrm{Otx} 2^{\text {flox/flox }}$ and five $\mathrm{En} 1^{\mathrm{Cre} /+}$; Otx $2^{\text {flox/flox }}$ mice received saline with the same schedule and served as controls. Sixteen hours after the last pCPA/ saline injection, brains were dissected. One hemisphere was used for immunohistochemistry, and the other for HPLC. For seizure studies, 10 $\mathrm{Otx} 2^{\text {flox/flox }}$ and $10 \mathrm{En} 1^{\mathrm{Cre} /+}$; Otx $2^{\text {flox/flox }}$ mice received a single intraperitoneal injection of KA (Ocean Produce International; dissolved in saline) at $20 \mathrm{mg} / \mathrm{kg}$. For pCPA plus KA treatments, mice ( $n=10$ per genotype), received the same dose of KA $16 \mathrm{~h}$ after the last pCPA injection. All experiments were performed blind to genotype and treatment.

Immunohistochemistry. Brains were fixed by immersion in $4 \%$ paraformaldehyde. Coronal or sagittal sections $(50 \mu \mathrm{m}$; cut on a freezing microtome) were incubated overnight with anti-5-HT (1:5000; SigmaAldrich; or 1:200; Millipore Bioscience Research Reagents) or anti-SERT (1:5000; Calbiochem) polyclonal antibodies, diluted in a PBS solution containing $1 \%$ serum and $0.1 \%$ Triton X-100. Sections were then reacted with a biotinylated secondary antibody (Vector Laboratories) followed by avidin-biotin-peroxidase complex (ABC kit; Vector Laboratories) and diaminobenzidine reaction. Quantitative analyses of immunohistochemistry experiments was performed as reported in the supplemental material (available at www.jneurosci.org).

HPLC. 5-HT was measured according to Atkinson et al. (2006). Brain areas (pons/ventral midbrain, hippocampus, and cerebral cortex) were dissected on ice, weighed to the milligram sensitivity, and extracted with a buffer containing $8.2 \%$ ascorbic acid, $1.64 \% \mathrm{Na}_{2} \mathrm{~S}_{2} \mathrm{O}_{5}$, and $0.83 \mathrm{M}$ $\mathrm{HClO}_{4}$. Extraction buffer volume (in microliters) corresponded to three times the weight in milligrams of the specimen. Homogenates were centrifuged ( $30 \mathrm{~min} ; 18,000 \mathrm{rpm} ; 4^{\circ} \mathrm{C}$ ), and supernatants were used as samples for HPLC. Standard solutions were prepared dissolving 5-HT and tryptophan (Sigma-Aldrich) in extraction buffer. Twenty microliters of samples or standards were injected into a Synergy Hydro-RP separation column, fitted with a 18 cartridge column (Phenomenex). The column was eluted isocratically $\left(0.8 \mathrm{ml} / \mathrm{min} ; 29^{\circ} \mathrm{C}\right)$ with mobile phase $(100 \mathrm{~mm}$ ammonium acetate, $\mathrm{pH}$ 4.5:methanol; $12.5: 1 \mathrm{v} / \mathrm{v}$ ) in a Waters Alliance HPLC apparatus. Detection was performed with a Waters 474 scanning fluorescence detector (excitation and emission wavelengths, 290 and 337 $\mathrm{nm}$, respectively), and data analysis was performed with Waters Millenium software. Values $( \pm \mathrm{SE})$ were reported as picomoles of $5-\mathrm{HT}$ per milligram of wet tissue. Statistical analysis was performed by one-way ANOVA followed by post hoc Tukey's test.
KA-induced seizures. Seizures were scored according to Racine (1972): stage 0 , normal behavior; stage 1 , immobility; stage 2 , forelimb and/or tail extension, rigid posture; stage 3 , repetitive movements, head bobbing; stage 4, forelimb clonus with rearing and falling (limbic motor seizure); stage 5 , continuous rearing and falling; stage 6 , severe wholebody convulsions (tonic-clonic seizures); stage 7, death. For each animal, seizure severity was scored every $20 \mathrm{~min}$ for $2 \mathrm{~h}$ after KA administration. The maximum rating scale values reached by each animal over each $20 \mathrm{~min}$ interval were used to calculate the rating scale value $( \pm \mathrm{SE})$ for each treatment group. Statistical analysis was performed by two-way repeated-measures ANOVA followed by post hoc Holm-Sidak test.

In situ hybridization. Mice ( $n=3$ per genotype and treatment group, chosen among those used for behavioral analysis) were killed at $2 \mathrm{~h}$ after KA injection. Nonradioactive in situ hybridization was performed on brain coronal sections using a digoxigenin-labeled c-fos riboprobe, as described previously (Costantin et al., 2005).

\section{Results}

We first analyzed the distribution of 5-HT and SERT in the ventral midbrain and hippocampus of drug-free $\mathrm{En} 1^{\mathrm{Cre} /+}$; $O t x 2^{\text {flox/flox }}$ mutant and Otx $2^{\text {flox/flox }}$ control adult mice. Immunohistochemistry experiments confirmed the presence of 5-HTpositive neurons in the ventral midbrain of $E n 1^{\mathrm{Cre} /+} ; \mathrm{O} t \times 2^{\text {flox/flox }}$ but not Otx $2^{\text {flox/flox }}$ mice (Fig. 1A) (Puelles et al., 2004). In the hippocampus, 5-HT staining was increased in the CA3 area of Otx 2 conditional mutant mice, compared with control mice (Fig. $1 A$ ). These findings were confirmed by quantitative analysis (see supplemental material, available at www.jneurosci.org). Conversely, SERT levels in serotonergic fibers were markedly reduced in these areas in $\mathrm{En1} \mathrm{Cre/+}^{\mathrm{CO}}$ Otx $2^{\text {flox/flox }}$ mice, when compared with control animals (Fig. $1 B$ ).

We next determined the 5-HT levels in different brain areas of $E n 1^{\text {Cre/+ }} ;$ Otx $2^{\text {flox/flox }}$ and Otx $2^{\text {flox/flox }}$ mice ( $n=5$ per genotype). HPLC analysis in Otx2 conditional mutant mice revealed a significant increase of 5-HT content in the pons/ventral midbrain, compared with control mice (Fig. 2A, saline-treated groups) (one-way ANOVA, $p<0.05$; post hoc Tukey's test, control vs mutant, $p<0.05)$. A slight but not significant increase of 5-HT content was detected in the whole hippocampus of $\mathrm{En1}^{\mathrm{Cre} /+}$; Otx $2^{\text {flox/flox }}$ compared with Otx $2^{\text {flox/flox }}$ mice (one-way ANOVA, $p>0.05$ ). According to our previous study (Borgkvist et al., 2006), 5-HT levels were also increased in the cerebral cortex of mutant mice (picomoles of 5-HT/milligram of tissue: salinetreated $O t \times 2^{\text {flox/flox }}, 1.71 \pm 0.19$; saline-treated $\mathrm{EnI}^{\mathrm{Cre} /+}$; Otx $2^{\text {flox/flox }}, 4.8 \pm 0.77$; one-way ANOVA, $p<0.05$; post hoc Tukey's test, $p<0.05)$. In both control and Otx2 conditional mutant mice ( $n=5$ per genotype), prolonged treatment with the 5-HT synthesis inhibitor pCPA significantly reduced 5-HT levels in the pons, ventral midbrain, and hippocampus (Fig. $2 \mathrm{~A}$ ). pCPA also decreased 5-HT content in the cerebral cortex in both genotypes (picomoles of 5-HT/milligram of tissue: pCPA-treated Otx $2^{\text {flox/flox }}, 0.98 \pm 0.16$; pCPA-treated $E n 1^{\text {Cre/+ }} ;$ Otx $2^{\text {flox/flox }}$, $1.7 \pm 0.5$; one-way ANOVA, $p<0.05$; post hoc Tukey's test, pCPA vs saline of same genotype, $p<0.05)$. 5 -HT levels in pCPAtreated $\mathrm{En}_{1} \mathrm{Cre} /+^{+}$; Otx $2^{\text {flox/flox }}$ mice did not significantly differ from those detected in saline-treated $O t x 2^{\text {flox/flox }}$ animals (Fig. 2A). 5 -HT immunohistochemistry performed on brain sagittal sections from saline- and pCPA-treated Otx $2^{\text {flox/flox }}$ and En1 ${ }^{\mathrm{Cre} /+}$; Ot $x 2^{\text {flox/flox }}$ mice confirmed these findings. According to our previous results (Fig. 1 A,B) (Borgkvist et al., 2006), increased 5-HT staining was detected in several areas including ventral midbrain, basal forebrain, cerebral cortex (Fig. $2 B$ ), and pons (raphe nuclei) (Fig. 2 B, C) of saline-treated En1 ${ }^{\text {Cre/+ }}$; Otx $2^{\text {flox/flox }}$ mutants, compared with saline-treated $O t x 2^{\text {flox/flox }}$ controls. Treatment with 

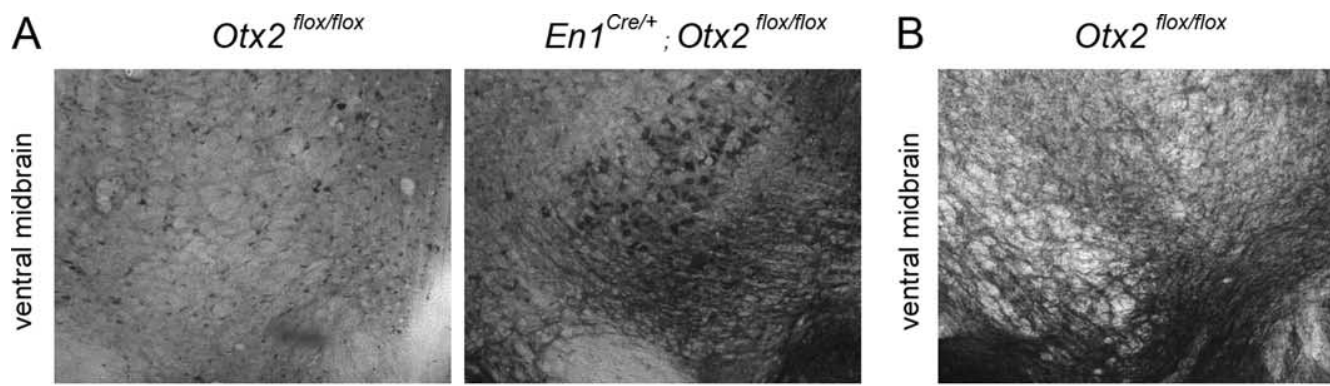

$E n 1^{\text {Cre/+ }} ;$ Otx $2^{\text {floxflox }}$

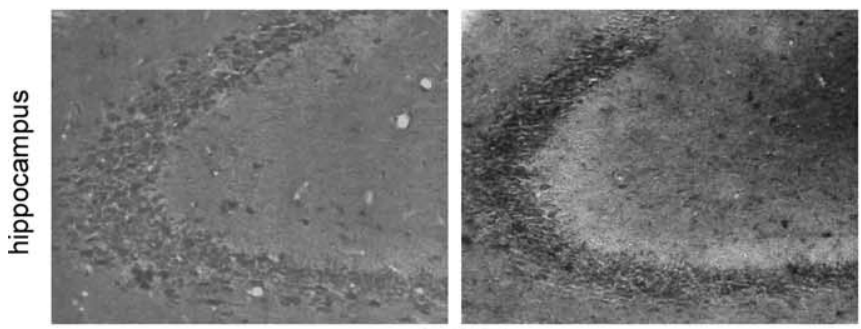

$5-\mathrm{HT}$

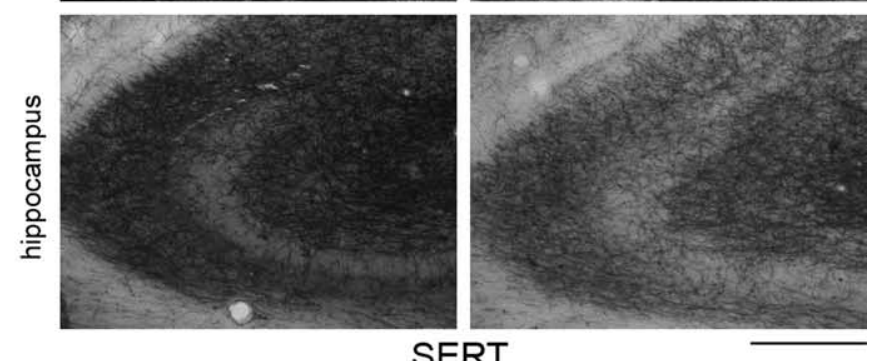

Figure 1. $5-\mathrm{HT}$ is increased and SERT is decreased in the ventral midbrain and hippocampus of Otx2 conditional mutant mice. $A, B$, Images show coronal sections through the ventral tegmental

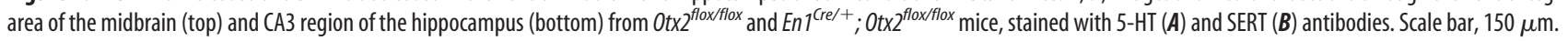

A

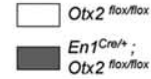

pons / ventral midbrain
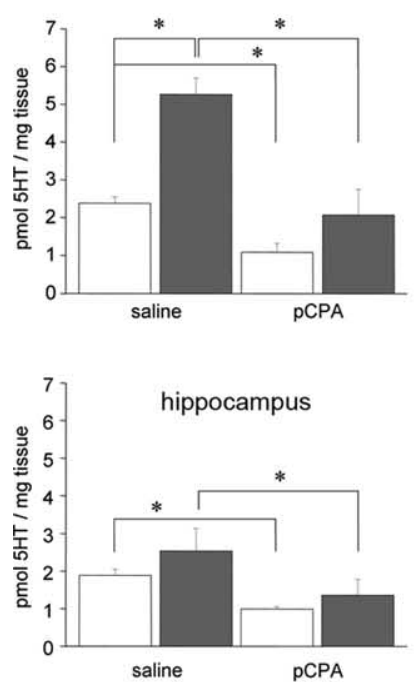

B
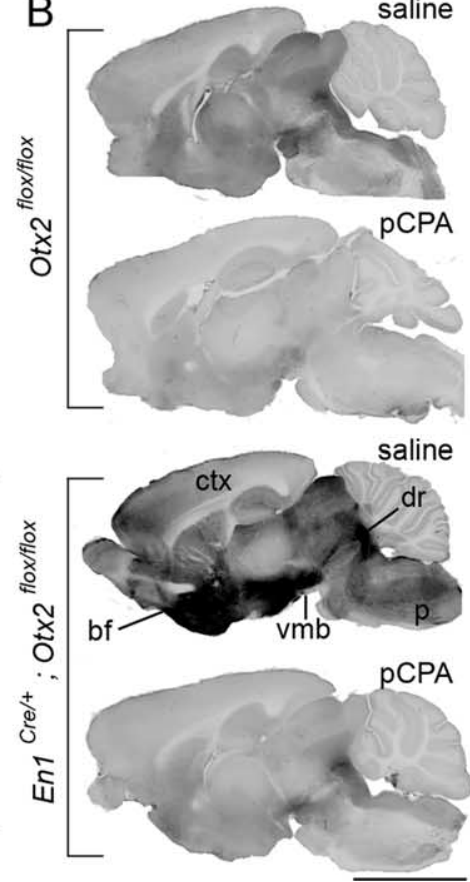

C
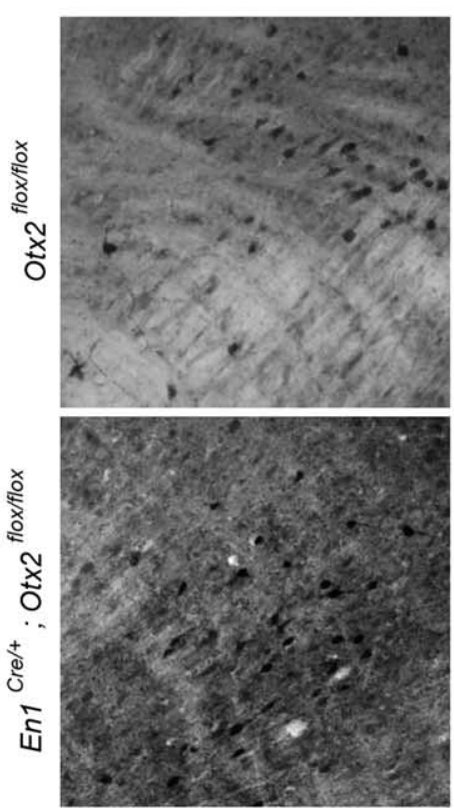

PCPA
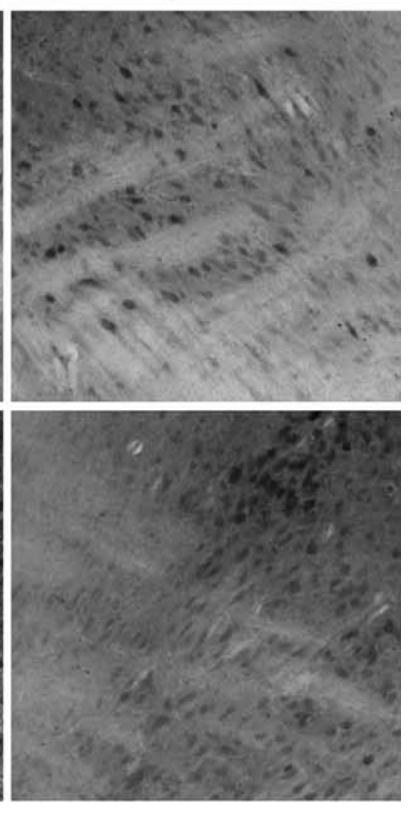

Figure 2. 5-HT depletion in control and Otx2 conditional mutant mice. A, HPLC determination of 5-HT content in the pons/ventral midbrain (top) and hippocampus (bottom) from Otx2 ${ }^{\text {flox }}$ flox and $E n 1^{\text {(re/+ }}$; Otx $2^{\text {floxflox }}$ mice, after a $3 \mathrm{~d}$ treatment with saline or pCPA. Data are reported as mean \pm SE $(n=5$ animals per group). * $p<0.05$, post hoc Tukey's test. $\boldsymbol{B}$, Representative low-magnification images showing 5-HT immunostaining on sagittal brain sections from control and Otx2 conditional mutant mice, treated with saline or pCPA. Genotypes and treatments are as indicated. Abbreviations: bf, Basal forebrain; ctx, cerebral cortex; dr, dorsal raphe nucleus; p, pons; vmb, ventral midbrain. Scale bar, 3.4 mm. C, Representative high-magnification images showing 5-HT immunostaining in the dorsal raphe nucleus from control and Otx2 conditional mutant mice, treated with saline or pCPA. Genotypes and treatments are as indicated. Scale bar, $150 \mu \mathrm{m}$.

pCPA markedly reduced 5-HT staining in all these areas in both genotypes (Fig. 2B,C). Quantitative analysis confirmed these findings (see supplemental material, available at www. jneurosci.org).

We next investigated whether increased 5-HT levels might alter seizure susceptibility in Otx2 conditional mutant mice. Adult $E n 1^{\mathrm{Cre} /+} ; \mathrm{Otx} 2^{\text {flox/flox }}$ and Otx $2^{\text {flox/flox }}$ mice $(n=10$ per genotype) received a single systemic injection of $\mathrm{KA}(20 \mathrm{mg} / \mathrm{kg})$ and were observed for $2 \mathrm{~h}$. KA treatment had a strong convulsant effect in $O t x 2^{\text {flox/flox }}$ mice. All mice showed initial immobility, rapidly followed by repeated generalized (stage 4-6) seizures (Fig. 3). The mean latency to the first generalized seizure in KAtreated Otx $2^{\text {flox/flox }}$ mice was $18.9 \pm 8.7 \mathrm{~min}$ (Table 1). Progression of clinical signs was dramatically different in $\mathrm{EnI}^{\mathrm{Cre} /+}$; Otx $2^{\text {flox/flox }}$ animals (Fig. 3). Indeed, the trajectory in behavior score of $\mathrm{En} 1^{\mathrm{Cre} /+} ; \mathrm{Otx} 2^{\text {flox/flox }}$ mice differed from that of control mice starting from $20 \mathrm{~min}$ after KA administration (two-way repeated-measures ANOVA, $p<0.001$; post hoc Holm-Sidak 


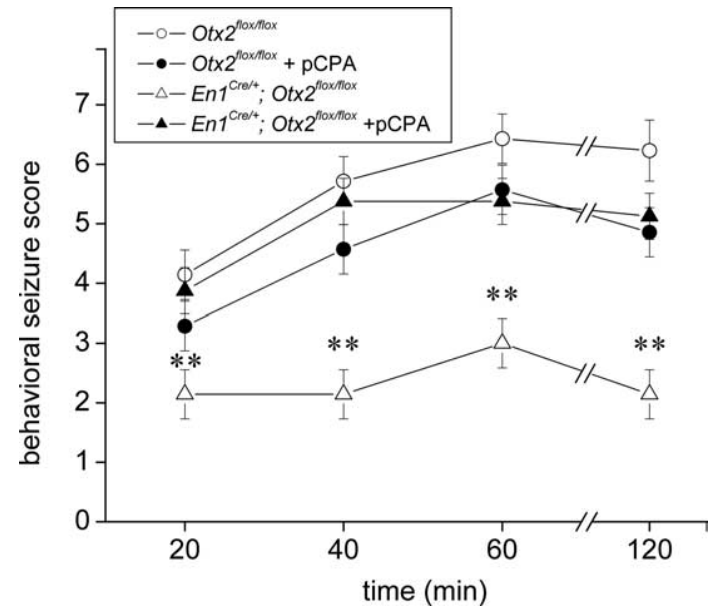

Figure 3. Resistance to KA-induced seizures in 0 tx 2 conditional mutant mice is abolished by 5-HT depletion. Graph shows the progression of behavioral changes over a $2 \mathrm{~h}$ observation period after KA in control and Otx2 conditional mutant mice, with or without PCPA pretreatment. Genotypes and treatments are as indicated. Data are reported as mean seizure scores \pm $\mathrm{SE}\left(n=10\right.$ animals per group). ${ }^{* *} p<0.001$, post hoc Holm-Sidak test, En $1^{\text {Cre/+ }} ; 0 t \times 2^{\text {flox }}{ }^{* f l o x}$ versus the other three treatment groups.

test, $\mathrm{En} 1^{\mathrm{Cre} /+} ; \mathrm{Otx} 2^{\text {flox/flox }}$ vs Otx $2^{\text {flox/flox }}$ mice, $\left.p<0.001\right)$. The majority of $O t x 2$ conditional mutant mice displayed only preconvulsive behaviors, never showing any sign of generalized seizure activity (Fig. 3). Only 1 of $10 \mathrm{En} 1^{\mathrm{Cre} /+} ; \mathrm{Otx} 2^{\text {flox/flox }}$ mice showed forelimb clonus with rearing and falling, followed by a single, brief tonic-clonic seizure. In this animal, latency to the first generalized seizure was $52 \mathrm{~min}$ (Table 1). En $1^{\mathrm{Cre} /+} ; \mathrm{Otx} 2^{\text {flox/flox }}$ never showed any sign of generalized seizure activity also at later times $(>2 \mathrm{~h}$ ) after KA administration (data not shown). Depletion of endogenous 5 -HT by pretreatment with pCPA in Otx2 conditional mutant mice $(n=10)$ resulted in the occurrence of strong KA-induced generalized seizures, as observed in Otx $2^{\text {flox/flox }}$ mice (Fig. 3). Indeed, seizure severity in $\mathrm{En}^{\mathrm{Cre} /+} ; \mathrm{Ot} \times 2^{\text {flox/flox }}$ pretreated with pCPA was significantly different from that observed in the same mice without pCPA (two-way repeated-measures ANOVA, $p<0.001$; post hoc Holm-Sidak test, En $1^{\mathrm{Cre} /+}$; Otx $2^{\text {flox/flox }}$ plus pCPA vs En1 $1^{\text {Cre/+ }} ;$ Otx $2^{\text {flox/flox }}, p<0.001$; $E n 1^{\text {Cre/+ }}$; Otx $2^{\text {flox } / \text { flox }}$ plus pCPA vs Otx $\left.2^{\text {flox } / \text { flox }}, p>0.05\right)$. Latency to first generalized seizure in $O t \times 2$ conditional mutant mice pretreated with pCPA was comparable with that observed in Otx $2^{\text {flox/flox }}$ mice (Table 1). Pretreatment with pCPA in $O t \times 2^{\text {flox/flox }}$ mice $(n=10)$ resulted in the same severity of KAinduced behavioral seizures as observed in Ot $2^{\text {flox/flox }}$ mice without pCPA and $E n 1^{\mathrm{Cre} /+}$; Otx $2^{\text {flox/flox }}$ mice pretreated with pCPA (two-way repeated-measures ANOVA, $p>0.05$; post hoc HolmSidak test, Otx $2^{\text {flox/flox }}$ plus pCPA vs Otx $2^{\text {flox/flox }}$ or $E n 1^{\mathrm{Cre} /+}$; Ot $x 2^{\text {flox/flox }}$ plus pCPA, $\left.p>0.05\right)$. Saline-treated animals of all genotypes never showed any sign of seizure activity (data not shown).

We next used c-fos mRNA in situ hybridization to study the pattern of brain activation at $2 \mathrm{~h}$ after KA. A strong c-fos mRNA labeling was observed in the septum, caudate-putamen, cerebral cortex, amygdala, hypothalamus, and hippocampus of Otx $2^{\text {flox/flox }}$ mice, whereas c-fos mRNA induction was restricted to the hippocampus in $\mathrm{En}_{1} \mathrm{Cre} /+^{+}$O Otx $2^{\text {flox/flox }}$ mice (Fig. 4). Conversely, En1 ${ }^{\mathrm{Cre} /+} ; \mathrm{Otx} 2^{\text {flox/flox }}$ mice pretreated with pCPA showed the same widespread c-fos mRNA labeling as observed in

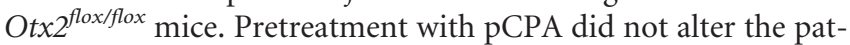
tern of KA-induced c-fos mRNA expression in Otx $2^{\text {flox/flox }}$ mice
(Fig. 4). Saline-treated animals of both genotypes did not show any c-fos mRNA labeling throughout the brain (data not shown).

\section{Discussion}

In this study, we show that conditional inactivation of the Otx2 gene in ventral midbrain results in increased 5-HT levels in several brain areas of $E n 1^{\text {cre/+}} ; \mathrm{Otx} 2^{\text {flox/flox }}$ adult mice. Behavioral and gene expression analyses showed that mutant mice were markedly resistant to KA-induced seizures. Seizure resistance was attributable to increased 5-HT levels, because 5-HT depletion by pCPA fully reestablished KA seizure susceptibility in $E n 1^{\text {cre/+}}$; Otx $2^{\text {flox/flox }}$ mice.

A link between 5-HT and seizure inhibition was originally suggested by the observation that anticonvulsant drugs elevated brain 5-HT levels (Bonnycastle et al., 1957). Several studies then confirmed a crucial role of 5-HT in the control of seizures. It is now generally accepted that drugs elevating extracellular 5-HT levels [such as selective serotonin reuptake inhibitors (SSRIs)] exert a powerful antiepileptic action. For example, the anticonvulsant effect of the SSRI fluoxetine has been clearly demonstrated in a wide variety of experimentally induced seizure models, as well as in genetically epileptic animals. Conversely, depletion of brain 5-HT content is known to decrease the threshold to evoked seizures in several experimental paradigms (Bagdy et al., 2007). Our study confirms and expands this notion. Indeed, we showed that genetically induced increase of 5-HT levels results in marked protection against KA-induced seizures.

Different 5-HT receptors have been shown to modulate seizure susceptibility and development of epilepsy. More specifically, the $5-\mathrm{HT}_{1 \mathrm{~A}}, 5-\mathrm{HT}_{2 \mathrm{C}}, 5-\mathrm{HT}_{3}$, and $5-\mathrm{HT}_{7}$ subtypes, which are all expressed in epileptogenic brain areas, are the most relevant in epilepsy (Bagdy et al., 2007). With respect to KA-induced seizures, the role of $5-\mathrm{HT}_{1 \mathrm{~A}}$ receptors has been clearly elucidated. Administration of 8-OH-DPAT [8-hydroxy-2-(di- $n$-propylamino)tetralin] (a specific $5-\mathrm{HT}_{1 \mathrm{~A}}$ agonist) reduces $\mathrm{KA}$-evoked seizures in rats (Gariboldi et al., 1996), whereas increased lethality after KA seizures is observed in mice with targeted inactivation of the 5- $\mathrm{HT}_{1 \mathrm{~A}}$ gene (Sarnyai et al., 2000). Mice lacking 5- $\mathrm{HT}_{2 \mathrm{C}}$ receptors also develop epilepsy (Tecott et al., 1995; Brennan et al., 1997). In KA seizure-resistant $E n 1^{\text {cre/+}}$; Otx $2^{\text {flox/flox }}$ mice, the role of 5-HT receptor signaling pathways remains to be elucidated.

Among the seizure models in which 5-HT plays a prominent role, DBA/2 mice have been well characterized. These mice are extremely prone to audiogenic or KA-induced seizures (Collins, 1972; Ferraro et al., 1995). Serotonin has been proposed to control seizure outcome in DBA/2 mice, because fluoxetine reduces respiratory arrest after audiogenic seizures (Tupal and Faingold, 2006). We used control and Otx2 conditional mutant mice of a mixed DBA/ $2 \times \mathrm{C} 57 \mathrm{BL} / 6$ background. Otx $2^{\text {flox/flox }}$ control mice never showed spontaneous seizures, but displayed high susceptibility to seizures induced by $20 \mathrm{mg} / \mathrm{kg} \mathrm{KA}$, similarly to what observed in DBA/2 mice (Ferraro et al., 1995; McLin and Steward, 2006) and mice with a mixed DBA/ $2 \times$ C57BL/6 background (Dell'agnello et al., 2007). Conversely, En1 ${ }^{\text {cre/+ }} ;$ Otx $2^{\text {flox/flox }}$ mice showed a marked resistance to KA seizures, indicating a protective effect of 5-HT in the mixed DBA/ $2 \times \mathrm{C} 57 \mathrm{BL} / 6$ background.

Seizure resistance in $\mathrm{En}^{\text {cre/+}} ; \mathrm{Otx} 2^{\text {flox/flox }}$ mice was also confirmed by gene expression studies. A precise correlation exists between the pattern of c-fos induction and the appearance of generalized seizures after KA. Preconvulsive behaviors (stages 1-3 of Racine's scale) induce c-fos mainly in the hippocampus, whereas generalized seizures (stages 4-6) result in a widespread expression in several brain areas (Willoughby et al., 1997; Bozzi et 
Table 1. Effect of 5-HT depletion on KA seizures in control and Otx2 conditional mutant mice

\begin{tabular}{|c|c|c|c|c|}
\hline & $0 t x 2^{\text {flox/flox }}$ & $E n 1^{(r e /+} ; 0 t x 2^{f l o x / f l o x}$ & $E n 1^{(r e /+} ; 0 t x 2^{f l o x / f l o x}+p C P A$ & $\begin{array}{l}0 t x 2^{\text {flox/flox }}+ \\
\text { pCPA }\end{array}$ \\
\hline No. of animals with generalized (stage $4-6$ ) seizures & 10 of 10 & 1 of $10^{a}$ & 10 of 10 & 10 of 10 \\
\hline Latency to first generalized (stage $4-6$ ) seizure ( $\mathrm{min}$ ) & $18.9 \pm 8.7^{b}$ & $52^{c}$ & $25 \pm 7.9$ & $32.3 \pm 12.7$ \\
\hline
\end{tabular}

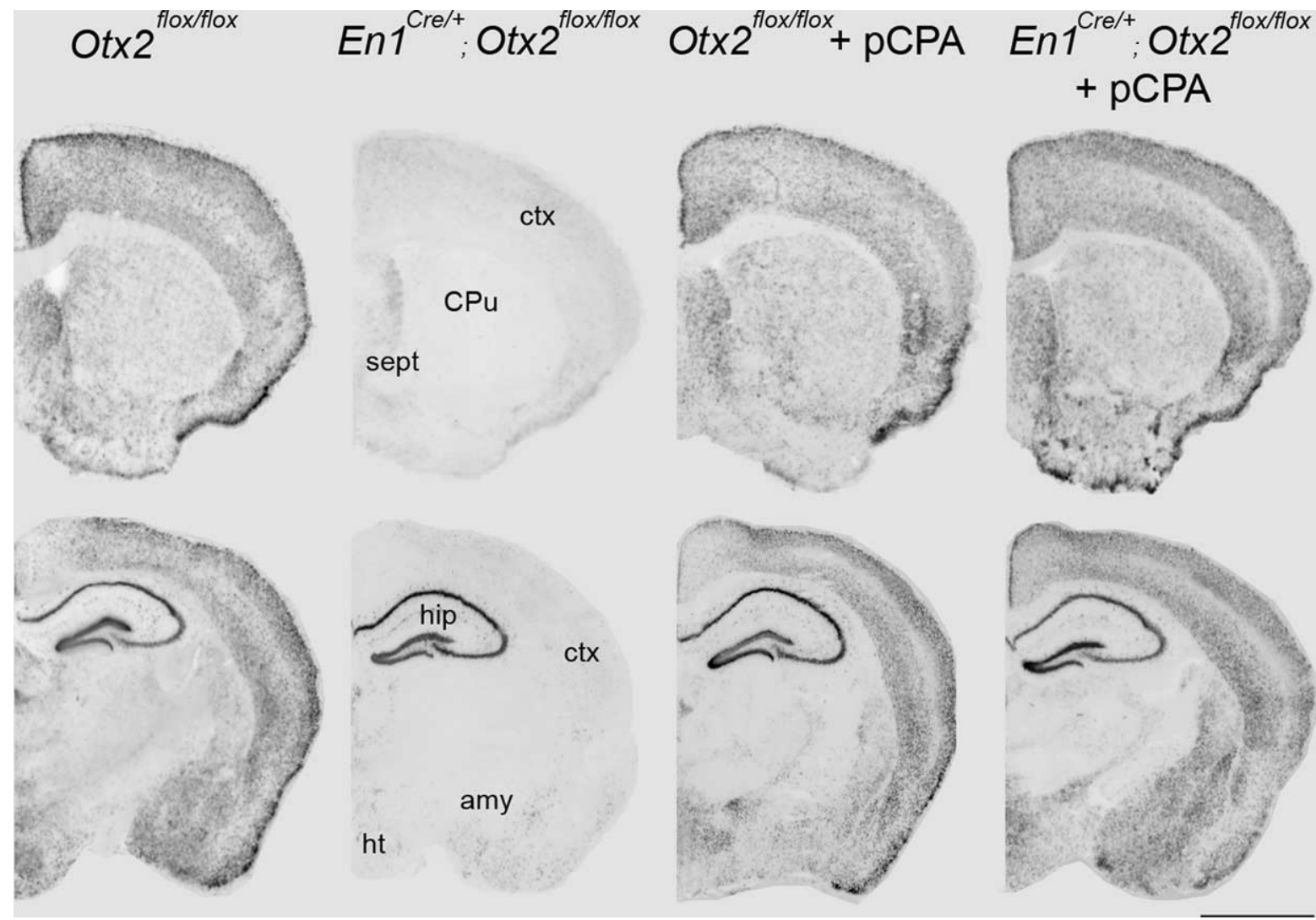

Figure 4. Effect of 5-HT depletion on c-fos mRNA expression in the brain of KA-treated control and Otx2 conditional mutant mice. The panels show c-fos mRNA in situ hybridizations on coronal sections at the level of the caudate-putamen (top) and dorsal hippocampus (bottom) from representative control and Otx2 conditional mutant mice (with or without $\mathrm{pCPA}$ pretreatment), $2 \mathrm{~h}$ after KA. Genotypes and treatments are as indicated. Abbreviations: amy, Amygdala; CPu, caudate-putamen; ctx, cerebral cortex; hip, hippocampus; ht, hypothalamus; sept, septum. Scale bar, 2 mm.

al., 2000). Accordingly, En1 $1^{\text {cre/+ }}$; Otx $2^{\text {flox/flox }}$ mice never experienced generalized seizures after KA, showing c-fos mRNA induction restricted to the hippocampus. Conversely, $E n 1^{\text {cre/+ }}$; Otx $2^{\text {flox/flox }}$ mice treated with pCPA, as well as Otx $2^{\text {flox/flox }}$ mice, showed KA-induced generalized seizures and widespread induction of c-fos mRNA.

The ventral midbrain and limbic system are crucially involved in the serotonergic control of seizures. For example, endogenous 5-HT transmission in the substantia nigra is able to inhibit the spread of seizure activity generated in the limbic system (Pasini et al., 1996). In En1 $1^{\text {cre/+ }} ;$ Otx $2^{\text {flox/flox }}$ mice, we detected increased levels of 5-HT in several brain areas, including the ventral midbrain, basal forebrain, cerebral cortex, and hippocampal CA3 subfield. Prolonged pretreatment of $E n 1^{\text {cre/+ }}$; Otx $2^{\text {flox/flox }}$ mice with the 5-HT synthesis inhibitor pCPA restored brain 5-HT content to control levels and abolished seizure resistance in mutant mice. This indicates that increased availability of synaptic 5-HT is indeed protective against KA seizures in $E n 1^{\text {crel+ }}$; Otx $2^{\text {flox/flox }}$ mice. Increased synaptic availability of 5-HT was also indicated by decreased SERT levels in the hippocampus and ventral midbrain of $\mathrm{En}^{\text {cre/+}}$; Otx $2^{\text {flox/flox }}$ mice. SERT decrease has been demonstrated to occur after prolonged elevation of 5-HT levels in mice (Mirza et al., 2007). Thus, in Otx2 conditional mutant mice, decreased SERT levels might be a consequence of increased 5-HT innervation.

$E n 1^{\mathrm{Cre} /+} ; \mathrm{Otx} 2^{\text {flox/flox }}$ mice show a strong reduction of DA cell number in the ventral midbrain (Puelles et al., 2004; Borgkvist et al., 2006). Therefore, it might be questioned that reduction of DA cells could also contribute to modify seizure susceptibility in these animals. DA, as 5-HT, is clearly involved in the control of epileptic seizures (Starr, 1996). A large series of studies strongly support the idea of an antiepileptic action of DA. Indeed, DA agonists inhibit convulsive seizures, both in experimental animals and humans. For example, the prototypical mixed $D_{1} / D_{2}$ receptor stimulant apomorphine has long been known to exert an antiepileptic action in humans (Starr, 1996). Mesolimbic DAergic pathways have been proposed to exert this inhibitory control (La Grutta and Sabatino, 1990; Starr, 1996). According to 
this view, DA reduction in the mesolimbic system of $E n 1^{\mathrm{Cre} /+}$; $O t \times 2^{f l o x / f l o x}$ mice would be expected to exacerbate seizure severity. In contrast, spontaneous or KA-induced seizures were never observed in $E n 1^{\mathrm{Cre} /+} ; \mathrm{Otx} 2^{\text {flox/flox }}$ mice, which instead displayed a marked resistance to KA. This suggests that, in this animal model, the effect of 5-HT hyperinnervation onto seizure control is more prominent than that of DA reduction.

Several studies suggest that there may be a link between epilepsy and depression, in which 5-HT would exert a crucial role. Epilepsy is often associated with depression in humans, and increased seizure susceptibility is accompanied by behavioral symptoms of depression in animal models (Mazarati et al., 2007). Moreover, serotonergic antidepressant drugs (such as fluoxetine) have anticonvulsant properties, and some antiepileptic drugs are effective in treating bipolar affective disorders (Jobe et al. 1999). We propose that $E n 1^{\mathrm{Cre} /+}$; Otx $2^{\text {flox/flox }}$ mutant mice, in which 5-HT hyperinnervation results in marked resistance to experimentally induced seizures, might serve as a novel genetic model to investigate the mechanisms underlying mood disorders.

\section{References}

Atkinson W, Lockhart SJ, Houghton LA, Keevil BG (2006) Validation of the measurement of low concentrations of 5-hydroxytryptamine in plasma using high performance liquid chromatography. J Chromatogr B Analyt Technol Biomed Life Sci 832:173-176.

Bagdy G, Kecskemeti V, Riba P, Jakus R (2007) Serotonin and epilepsy. J Neurochem 100:857-873.

Ben-Ari Y (1985) Limbic seizures and brain damage produced by kainic acid: mechanisms and relevance to human temporal lobe epilepsy. Neuroscience 14:375-403.

Bonnycastle DD, Giarman NJ, Paasonen MK (1957) Anticonvulsant compounds and 5-hydroxytryptamine in rat brain. Br J Pharmacol Chemother 12:228-231.

Borgkvist A, Puelles E, Carta M, Acampora D, Ang SL, Wurst W, Goiny M, Fisone G, Simeone A, Usiello A (2006) Altered dopaminergic innervation and amphetamine response in adult Otx 2 conditional mutant mice. Mol Cell Neurosci 31:293-302.

Bozzi Y, Vallone D, Borrelli E (2000) Neuroprotective role of dopamine against hippocampal cell death. J Neurosci 20:8643-8649.

Brennan TJ, Seeley WW, Kilgard M, Schreiner CE, Tecott LH (1997) Sound-induced seizures in serotonin 5-HT2C receptor mutant mice. Nat Genet 16:387-390.

Collins RL (1972) Audiogenic seizures. In: Experimental models of epilepsy: a manual for the laboratory worker (Purpura DP, Penry JK, Tower DB, Woodbury DM, Walter RD, eds), pp 347-372. New York: Raven.

Costantin L, Bozzi Y, Richichi C, Viegi A, Antonucci F, Funicello M, Gobbi M, Mennini T, Rossetto O, Montecucco C, Maffei L, Vezzani A, Caleo M (2005) Antiepileptic effects of botulinum neurotoxin E. J Neurosci 25:1943-1951.

Dell'agnello C, Leo S, Agostino A, Szabadkai G, Tiveron C, Zulian A, Prelle A, Roubertoux P, Rizzuto R, Zeviani M (2007) Increased longevity and refractoriness to $\mathrm{Ca}^{2+}$-dependent neurodegeneration in Surfl knockout mice. Hum Mol Genet 16:431-444.

Ferraro TN, Golden GT, Smith GG, Berrettini WH (1995) Differential susceptibility to seizures induced by kainic acid. Epilepsia 36:301-307.

Gariboldi M, Tutka P, Samanin R, Vezzani A (1996) Stimulation of 5-HT1A receptors in the dorsal hippocampus and inhibition of limbic seizures induced by kainic acid in rats. Br J Pharmacol 119:813-818.

Jobe PC, Dailey JW, Wernicke JF (1999) A noradrenergic and serotonergic hypothesis of the linkage between epilepsy and affective disorders. Crit Rev Neurobiol 13:317-356.
La Grutta V, Sabatino M (1990) Substantia nigra-mediated anticonvulsant action: a possible role of a dopaminergic component. Brain Res 515:87-93

Lothman EW, Collins RC (1981) Kainic acid induced limbic seizures: metabolical, behavioral, electroencephalographic and neuropathological correlates. Brain Res 218:299-318.

Mazarati A, Shin D, Auvin S, Caplan R, Sankar R (2007) Kindling epileptogenesis in immature rats leads to persistent depressive behavior. Epilepsy Behav 10:377-383.

Mazarati AM, Baldwin RA, Shinmei S, Sankar R (2005) In vivo interaction between serotonin and galanin receptors types 1 and 2 in the dorsal raphe: implication for limbic seizures. J Neurochem 95:1495-1503.

McLin JP, Steward O (2006) Comparison of seizure phenotype and neurodegeneration induced by systemic kainic acid in inbred, outbred, and hybrid mouse strains. Eur J Neurosci 24:2191-2202.

Mirza NR, Nielsen EØ, Troelsen KB (2007) Serotonin transporter density and anxiolytic-like effects of antidepressants in mice. Progr Neuropsychopharmacol Biol Psychiatry 31:858-866.

Pasini A, Tortorella A, Gale K (1996) The anticonvulsant action of fluoxetine in substantia nigra is dependent upon endogenous serotonin. Brain Res 724:84-88.

Prakash N, Brodski C, Naserke T, Puelles E, Gogoi R, Hall A, Panhuysen M, Echevarria D, Sussel L, Weisenhorn DM, Martinez S, Arenas E, Simeone A, Wurst W (2006) A Wnt1-regulated genetic network controls the identity and fate of midbrain-dopaminergic progenitors in vivo. Development 133:89-98.

Puelles E, Acampora D, Lacroix E, Signore M, Annino A, Tuorto F, Filosa S, Corte G, Wurst W, Ang SL, Simeone A (2003) Otx dose-dependent integrated control of antero-posterior and dorso-ventral patterning of midbrain. Nat Neurosci 6:453-460.

Puelles E, Annino A, Tuorto F, Usiello A, Acampora D, Czerny T, Brodski C, Ang SL, Wurst W, Simeone A (2004) Otx2 regulates the extent, identity and fate of neuronal progenitor domains in the ventral midbrain. Development 131:2037-2048.

Racine RJ (1972) Modification of seizure activity by electrical stimulation. II. Motor seizure. Electroencephalogr Clin Neurophysiol 32:281-294.

Rantamäki T, Hendolin P, Kankaanpää A, Mijatovic J, Piepponen P, Domenici E, Chao MV, Männistö PT, Castrén E (2007) Pharmacologically diverse antidepressants rapidly activate brain-derived neurotrophic factor receptor TrkB and induce phospholipase-Cgamma signaling pathways in mouse brain. Neuropsychopharmacology 32:2152-2162.

Sarnyai Z, Sibille EL, Pavlides C, Fenster RJ, McEwen BS, Toth M (2000) Impaired hippocampal-dependent learning and functional abnormalities in the hippocampus in mice lacking serotonin(1A) receptors. Proc Natl Acad Sci U S A 97:14731-14736.

Schauwecker PE, Steward O (1997) Genetic determinants of susceptibility to excitotoxic cell death: implications for gene targeting approaches. Proc Natl Acad Sci U S A 94:4103-4108.

Simeone A (2005) Genetic control of dopaminergic neuron differentiation. Trends Neurosci 28:62-65; discussion 65-66.

Simeone A, Puelles E, Acampora D (2002) The Otx family. Curr Opin Genet Dev 12:409-415.

Starr MS (1996) The role of dopamine in epilepsy. Synapse 22:159-194.

Tecott LH, Sun LM, Akana SF, Strack AM, Lowenstein DH, Dallman MF, Julius D (1995) Eating disorder and epilepsy in mice lacking 5-HT2C serotonin receptors. Nature 374:542-546.

Tupal S, Faingold CL (2006) Evidence supporting a role of serotonin in modulation of sudden death induced by seizures in DBA/2 mice. Epilepsia 47:21-26.

Willoughby JO, Mackenzie L, Medvedev A, Hiscock JJ (1997) Fos induction following systemic kainic acid: early expression in the hippocampus and later widespread expression correlated with seizure. Neuroscience 77:379-392. 